\title{
Pituitary Responses to a Neuroactive Tripeptide (TRH) in Friedreich's Ataxia Families
}

\author{
G. TOLIS*, A. MEHTA*, E. ANDERMANN**, C. HARVEY**, A. BARBEAU***
}

\begin{abstract}
Oral glucose tolerance, thyroid function tests, as well as thyrotropin, prolactin and growth hormone release after administration of thyrotropin releasing hormone, were evaluated in patients with Friedreich's ataxia and unaffected family members. Impaired glucose tolerance was found in the majority of family members, affected or not. Thyroid hormone levels and PRL and $T S H$ responses to TRH, were similar in all and normal. However, $G H$ responses to $T R H$ were abnormal in half of the patients, but in none of the unaffected family members. Paradoxical responses to neuropeptides may characterize some Friedreich's ataxia patients, and may predict the possibility of therapeutic maneuvers with such peptides in these patients.
\end{abstract}

RÉSUMÉ: Nous avons évalué chez des patients avec ataxie de Friedreich, et leurs familles, les tests de tolérance orale au glucose, de fonction thyroidienne ainsi que la libération de thyrotropine, de prolactine et d'hormone de croissance après l'administration de l'hormone thyrotropinerelâchante. Nous avons trouvé une anomalie de la tolérance au glucose chez la majorité des sujets examinés, atteints ou pas. Les réponses à la stimulation TRH étaient toutes semblables et normales. Cependant la réponse de l'hormone de croissance au TRH était anormale chez la moitié des patients, mais chez aucun des membres non atteints de la famille. Des réponses paradoxales aux neuropeptides peuvent caractériser quelques patients ataxiques, et peuvent prédire la possibilité de maneuvres thérapeutiques.

* Department of Medicine, Division of Endocrinology Royal Victoria Hospital

** Department of Neurogenetics, Montreal Neurological Hospital and Institute, McGill University

*** Institut de recherches cliniques de Montréal, Montreal, Quebec, Canada.

Reprint requests for the entire supplement on Friedreich's Ataxia (Phase Three, Part Two) to: Prof. André Barbeau, Clinical Research Institute of Montreal, 110 West Pine Avenue, Montréal, Quebec, Canada, H2W $1 R 7$.

\section{INTRODUCTION}

Thyrotropin releasing hormone (TRH) is a peptide which is present not only in the hypothalamus, but also in other areas of the central nervous system (Reichlin, 1979). As a hypothalamic hormone, it seems to be the main controlling factor of thyrotropin (TSH) secretion, although it also releases prolactin (PRL) under normal circumstances, and ACTH and $\mathrm{GH}$ in some patients with ACTH and GH excess (Tolis et al, 1975; Pieter et al, 1979). Furthermore, TRH administration acutely stimulates $\mathrm{GH}$ release in some patients with depression and anorexia nervosa (Jarrel et al, 1974).

Aside from the purely endocrine effects of TRH, recent reports have indicated that it may ameliorate some of the symptoms in certain disease of the central nervous system, e.g. depression, Parkinson's disease, and narcolepsy (Chase et al, 1974; Prange et al, 1972). An alleviation of the ataxia and eyemovement disorder seen in spinocerebellar ataxia (Sobue et al, 1980) and improvement of the neurologic recovery after spinal trauma have also been reported (Faden et al, 1981).

Our study reports the preliminary results of the effects of TRH on TSH, PRL and GH release in patients with Friedreich's ataxia and their family members.

\section{SUBJECTS AND METHODS}

The study was performed in 26 family members ( 7 families). Nine subjects were patients, 9 were parents (obligate heterozygotes) and 8 were unaffected siblings. The age ranges of the patients were $16-45$ years, mean 26.6 ; the parents $38-73$ years, mean 54.8 ; and unaffected siblings $13-47$ years, mean
31.75 respectively. There was a total of 14 males and 12 females studied.

All patients had been asked to come for testing after overnight fasting. There were two tests performed in all. At first, they underwent an oral glucose tolerance, as previously described (Tolis et al, 1980). One to three months later, they came for the TRH test.

Blood was collected via an indwelling catheter at 15 -minute intervals for 75 minutes. TRH (200 ug) was injected intravenously at time 0 ' after two basal blood samples were collected. Serum Thyroxine, T3 resin uptake and triiodothyronine were measured in all the patients on the basal sample (Bastomsky et al, 1977). Serum TSH, PRL and GH were measured in all blood samples with standard radioimmunoassays (Tolis, Banovac et al, 1979).

\section{RESULTS \\ A. Oral Glucose Tolerance}

Analysing the data on the basis of previously utilized N.I.H. criteria, we classified one patient and one unrelated parent as having a diabetic curve and five patients, five parents and five siblings as having impaired glucose tolerance (I.G.T.) (Tolis et al, 1980).

\section{B. Thyroid Function Test}

All family members (affected individuals, obligate heterozygotes (parents), and unaffected siblings) had normal serum T4, T3 and TSH values (Table 1).

\section{Results of the TRH Test \\ 1. TSH and PRL}

These are depicted in Figure 1. It can be seen that all 3 groups had comparable results which are within the normal range. Note also that the time 
TRH INFUSION TEST IN FRIEDREICH'S ATAXIA

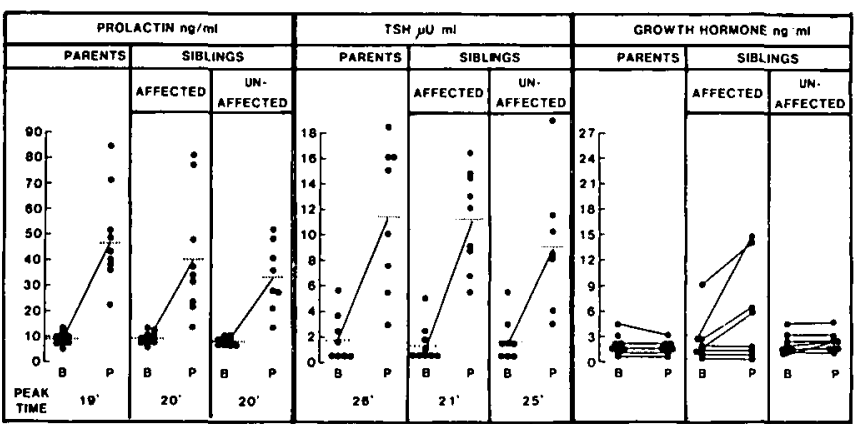

Figure I - Pituitary responses to TRH (200 ug i.v.) in patients with Friedreich's ataxia and their relatives.

B: denotes basal $\mathbf{P}$ : denotes peak levels

Peak time: denotes the time that hormones in blood reached maximum levels.
Table I. SERUM THYROXINE (T4), TRIIODOTHYRONINE (T3RIA) AND THYROTROPIN (TSH) VALUES IN FRIEDREICH'S ATAXIA PATIENTS AND THEIR FAMILY MEMBERS. at which maximum concentrations of hormones in serum was reached was also normal and did not differ among the groups.

\section{2. $G H$}

All of the unaffected family member, i.e. parents and siblings, had normal fasting serum $\mathrm{GH}$ levels; in contrast, 4 of the 8 patients had abnormalities in GH secretions. One patient had elevated fasting serum $\mathrm{GH}(9.9 \mathrm{ng} / \mathrm{ml})$ and all four showed an inappropriate rise after TRH (Figure 1). These abnormalities appeared to be independent of the OGTT results, and of the responses of TSH and PRL to TRH.

\section{DISCUSSION}

Our data indicate that administration of the neuroactive tripeptide TRH in patients with Friedreich's ataxia as well as in obligate heterozygotes (parents), and in potential carriers (unaffected siblings) elicits a normal TSH and PRL response, which is comparable among all three groups (Figure 1). This response pattern was not affected by the presence of abnormal glucose tolerance, and was associated with normal thyroid hormone levels (see Table 1). In contrast, 4 of 8 patients with Friedreich's ataxia exhibited abnormal GH levels and/or responses to TRH. As indicated earlier, in the absence of nutritional deprivation or psychiatric disorder, the main medical conditions where paradoxical $\mathrm{GH}$ responses to TRH may be seen are primary hypothyroidism and acromegaly. Since our families did not suffer from either condition, other mechanisms should be sought. It is of interest, that, in acromegaly, TRH induces $\mathrm{GH}$ responses mainly in those patients harbouring tumours which have dopamine receptors (Tolis, McKenzie et al, 1979). As a matter of fact, TRH is used as a predictor with respect to medical therapy of acromegaly with bromocriptine or dopamine receptor agonist drugs (Mehta and Tolis, 1979). Since some of the patients with Friedreich's ataxia may show some improvement with TRH (Sobue et al, 1980), it may be of interest in future to demonstrate an association between a neuroendocrine response pattern and treatment with neuroactive agents.

\section{REFERENCES}

BASTOMSKY, C., DENT, R., TOLIS, G. (1977). Elevated serum TBG and ceruloplasmin in methadone maintained patients. Clin. Biochem. 10 (3): 124-126.

CHASE, T.N., WOODS, A.C., LIPTON, M.A. MORRIS, C.E. (1974). Hypothalamic releasing factors and Parkinson's disease. Arch. Neurol., 31, 55-56.

FADEN, A.I., JACOBS, T.P., HOLADAY, J.W. (1981). TRH improves neurologic recovery after spinal trauma in cats. N.E. J.M., 305: 1063-1067.

JARRELL, J., MELTZER, S., TOLIS, G. (1979). Anorexia nervosa: a review of the endocrine abnormalities in the hypothalamic pituitary axis. in: Clinical Neuroendrocinology - a pathophysiological approach. (Tolis, G., Labrie, F., Martin, J.B. and Naftolin, F., eds.). Raven Press, New York, pp. 355-365.

MEHTA, A., TOLIS, G. (1979). Bromocriptine. Drugs 17: 313-325.

PIETERS, G.F., SMALS, A.G., BENRAAD, T.J., KLOPPENBORG, P.W.C. (1979). Plasma cortisol responses to TRH and LHRH in Cushing's disease. J. Clin. Endocrinol. Metab. 48: 874-876.

PRANGE, A.J. JR., WILSON, I.C., LARA, P.P., ALLTOP, L.B., BREASE, G.R. (1972). Effects of TRH in depression. Lancet, 2: 999-1002.

REICHLIN, S. (1979). Overview of the anatomical and physiologic basis of anterior-pituitary regulation. in: Clinical Neuroendrocrinology - a pathophysiological approach. (Tolis, G., Labrie, F., Martin, J.B. and Naftolin, F., eds.) Raven Press, New York, pp. 1-14.

SOBUE, I., YAMAMOTO, H., KONAGAYA, M., LIDA, M., TAKAYANAGI, T. (1980). Effect of TRH on ataxia of spino-cerebellar degeneration. Lancet 1, 418-419.

TOLIS, G., MARTIN, J.B. KOVACS, L., FRIESEN, H.G. (1975). GH and PRL secretory pattern in active acromegaly. Acta Endocrinol. 78: 251-257.

TOLIS, G., BANOVAC, K., MACKENZIE, J.M., GUYDA, H. (1979). Circadian rhythms of anterior pituitary hormone secretion. J. Endocrinol. Invest. 2: 433-436.

TOLIS, G., McKENZIE, J.M., MARTIN, J.B., BERTRAND, G. (1979). Growth hormone secreting pituitary tumors: Clinical presentation, diagnostic tests and therapeutic modalities. In: Clinical Neuroendocrinology - a pathophysiological approach. (Tolis, G., Labrie, F., Martin, J.B. and Naftolin, F., eds.) Raven Press, New York, pp. 437-448.

TOLIS, G., MEHTA, A., ANDERMANN, E., HARVEY, C., BARBEAU, A. (1980). Friedreich's ataxia and oral glucose tolerance. Can. J. Neurol. Sci. 7(4): 397 400 . 